\title{
Transfer Fiyatlandırması Uygulamaları: Seçilmiş Ülkeler Açısından Bir Değerlendirme*
}

\author{
Ahmet Kemal ÇELEBI ${ }^{* *}$
}

\author{
Pelin MASTAR ÖZCAN ${ }^{* * *}$
}

\begin{abstract}
$\ddot{O} Z$
Küreselleşme süreciyle birlikte sermayenin önündeki engellerin kalkmış bu sayede sermaye uluslararası bir nitelik kazanmış ve bu durum çok uluslu şirketlerin var olmasına olanak sağlamıştır. Günümüzde çok uluslu şirketlerin yarattıkları ekonomik değer büyük boyutlara ulaşmıştır. Çok uluslu şirketlerden beklenilen vergisel yükümlüklerini zamanında yerine getirerek yatırım yaptıkları ülkelerin vergi gelirlerine olumlu katkı yapmalarıdır. Ancak uygulamada çok uluslu şirketler mümkün olduğunca vergisel yükümlüklerinden kaçınmaya çalışmakta ve böylelikle ülkelerin vergi tabanlarının aşınmasına neden olmaktadır. Bu kapsamda çok uluslu şirketlerin vergi yüklerini azaltmak için başvurdukları yöntemlerden biri de transfer fiyatlandırmasıdır. Transfer fiyatlandırması uygulamalarında kullanılan yöntemler açısından ülkeler genellikle OECD'nin önermiş olduğu transfer fiyatlandirması yöntemleri kabul edilmiştir. Dolaylsıyla son dönemde ülkelerin transfer fiyatlandırması incelemelerini daha etkin hale getirmeye çalıştıkları gözlemlenmektedir. Bu kapsamda çalışmada tr

Transfer fiyatlandırması denetimlerini en etkin şekilde gerçekleştiren ülkelerden olan Japonya, Hindistan, Çin Halk Cumhuriyeti, Kanada ve Amerika Birleşik Devlet'lerinin transfer fiyatlandırması uygulamaları değerlendirilmiştir.
\end{abstract}

Anahtar Kelimeler: Çok Uluslu Şirket, Transfer Fiyatlandırması, Risk Denetimi

JEL Sinıflandirması:F23, H26, M42.

\section{Transfer Pricing Practices: An Evaluation For Selected Countries}

\begin{abstract}
As an effect of globalization proccess, removal of restraints for funds and therefore the fact that those funds are gaining international characteristics have enabled the availability of multinational companies. Nowadays, the economic values produced by those multinational companies have reached very large extents. Multinational companies provide positive contribution for the tax incomes of countries in which they fulfill their tax obligations as expected on time. However, in practice, multinational companies are tend to avoid those obligations as possible and therefore cause a corrosion in the tax base of those countries. Within this scope, one of the methods that used by multinational companies in an attempt to decrease their tax incidences is transfer pricing. The methods of transfer pricing which have been suggested by OECD are accepted as transfer pricing practices. This implies that, more recently, countries try to reenforce the inquisitions of transfer pricing practices. In this context, transfer pricing practices of Japan, India, People's Republic of China, Canada and United States of America, which are some of the countries that apply transfer pricing inquisitions efficiently are evaluated.
\end{abstract}

Key Words: Multinational Company, Transfer Pricing, Risk Analysis

JEL Classification:F23, H26, M42.

\footnotetext{
"Bu çalışma "Çok Uluslu Şirketlerin Vergilendirilmesi: Transfer Fiyatlaması Açısından Bir Değerlendirme”" isimli doktora tezinden üretilmiştir

** Prof. Dr., Manisa Celal Bayar Üniversitesi, İ̈BF, Maliye Bölümü, kemal.celebi@ cbu.edu.tr

**** Yrd. Doç. Dr., Manisa Celal Bayar Üniversitesi, İ̈BF, Maliye Bölümü, pelin.mastar@cbu.edu.tr
} 


\section{GíRIŞ̧}

Küreselleşme sürecinin ekonomik sonuçlarından birisi de küresel ticaretin yaygınlaşması neticesinde çok uluslu şirketlerin oluşmasıdır. Sermayenin uluslararası niteliğe kavuşması, çok uluslu şirketlerin farklı ülkelerde bağlı şirketler ya da iştirakler halinde örgütlenmesi ile olmuştur. Çok uluslu şirketler dünya ticaretinin yaklaşık \%60'nı gerçekleştirmekte olup bu ticaret hacminin yaklaşık yarısını ilişkili kuruluşlarıyla gerçekleştirmektedir. Bu ilişkilerinde vergi sonrasını karlarını maksimize edebilmek için transfer fiyatlandırmasından yararlanmaktadırlar. Özellikle 2008 krizinden sonra ülkelerin vergi gelirlerinde yaşanan azalma çok uluslu şirketlerin neden oldukları vergi kayıplarının tekrar kamuoyunun gündemine taşınmasına neden olmuştur. Bu kapsamda özellikle OECD tarafından yürürlüğe giren Matrah Aşındırma ve Kar Aktarımı Eylem Planı (BEPS-Base Erosionand Profit Shifting) ile çok uluslu şirketlerin agresif vergi planlaması ile neden oldukları vergi kayıplarının önlenmesi amaçlanmıştır. Eylem Planı'nın genel amacını, ekonomik faaliyet hangi ülkede yapılmıssa ve değer nerde üretilmişse o ülke tarafından vergilendirme hakkının kullanılmasını sağlamak olarak özetlememiz mümkündür (Kara ve Öz, 2016:174). On beş eylem planının yer aldığı çalışmada matrahın aşındırılması ve kârın aktarılması konusunda yapılması gereken faaliyetler belirlenmiş olup bu eylemlerin temelini transfer fiyatlandırmasına ilişkin düzenlemeler ve belgelendirme yükümlülüğü oluşturmaktadır.

\section{TRANSFER FIYYTLANDIRMASI KAVRAMI}

İşletme bilimine göre transfer fiyatı; işletmelerin coğrafik ve işlevsel olarak bölünmelerinin neticesinde birimler arasında rekabetin olmadığı bir ortamda mal ve hizmet alımında kullanılan fiyat olarak tanımlanmaktadır (Öcal, 2010:35). OECD'nin 2010 yılında yayımladığı Çok Uluslu Şirketler ve Vergi İdareleri için Transfer Fiyatlandirması Rehberi (Transfer Pricing Guidelines for Multinational Enterprises and Tax Administrations) transfer fiyatını; bir işletmenin mal, gayri maddi hak veya hizmetlerinin bağlı bir işletmeye satış fiyatı şeklinde tanımlanmaktadır (OECD, 2010:19).

Başka bir ifade ile transfer fiyatlandırması; işletmelerin bağlı işletmelerle yaptıkları maddi ve gayri maddi mal veya hizmet transferinin, kiralamaların ve ödünç alımlarının fiyatlandırılmasını ifade etmektedir (Ateş,2011:1). Transfer fiyatlandırmasının en önemli özelliği, bu fiyatın serbest piyasada, birbirinden bağımsız kişiler arasında benzer şartlar altında oluşan fiyattan farklı bir fiyat olmasıdır. Böyle bir fiyat politikasının temel amacı; vergi yükünün azaltılmak istenmesidir (Pehlivan, 2006:80).

\section{SEÇILMISS ÜLKELERDE TRANSFER FIYYTLANDIRMASI DÜZENLEMELERİ}

Transfer fiyatlandırması çok uluslu şirketlerin gelişmesine bağlı olarak tüm dünyada uygulanan bir müessese haline gelmiştir. İncelenen ülkelerin seçiminde; transfer fiyatlandırmasına yönelik yapılan düzenlenmelerin genişliği ve transfer fiyatlandırması incelemelerinin yoğunluğu ve etkinliği göz önünde tutulmuş olup 
bu kapsamda Japonya, Hindistan, Çin Halk Cumhuriyeti, Kanada, Amerika Birleşik Devletleri'nde uygulanan transfer fiyatlandırması kuralları ve denetim süreci incelenmiştir.

\section{A.Japonya}

Japonya'da transfer fiyatlandırmasına ilişkin ilk düzenleme 1986 yılında yürürlüğe giren kanunun (The Special Taxation Measures Law-STML) 66/4. maddesi ile yapılmıştır. Söz konusu madde uyarınca; vergi mükellefi kurumun yabancı bir ülkede bulunan ilişkili kişilerle gerçekleştirdikleri tüm işlemleri emsal fiyata uygun bir şekilde gerçekleşmelidir. Emsal fiyata aykırı bir şekilde belirlenen fiyatlar ile gerçekleşen işlemlerin tespit edilmesi durumunda gerekli düzeltmelerin idare tarafindan yapılması gerekmektedir (Fujimari ve Okada, 2009:441). Bu düzeltme işlemi ile amaçlanan şirketlerin gerçekleştirdikleri işlemler sonucunda elde ettikleri gerçek gelirin vergilendirmesi olup düzeltme işlemeleri sadece uluslararası işlemleri kapsamaktadır. Yabancı ilişkili şirketin Japonya'da daimi temsilciliğinin bulunması halinde Japonya'da elde edilen kazanç üzerinden düzeltme işlemi yapılamamaktadır (De Mooij ve Saito, 2014:11). Bu genel kuralın istisnasını hazine zararı oluşturmaktadır. Hazine zararının söz konusu olması halinde yabancı yatırımcıların yurt içi işlemleri de değerlendirmeye alınmaktadır. $\mathrm{Bu}$ açıdan yurtdışındaki ilişkili şirket diğer ülkelere nazaran daha belirgin bir şekilde tanımlanmıştır. Japon Vergi Kanunlarına göre bir şirketin ilişkili şirket olarak kabul edilebilmesi için aşağıdaki koşullardan en az birinin gerçekleşmesi gerekmektedir (Yoshımura, 2013:45):

- Yurtdışındaki kurum, vergi mükellefine veya vergi mükellefi yurt dışındaki kuruma doğrudan veya dolaylı olarak en az \%50 oranında ortaksa,

- Üçüncü bir kişi, vergi mükellefine ve yurtdışındaki kuruma doğrudan veya dolaylı olarak en az \%50 oranında ortaksa,

- Yurt dışındaki kurum vergi mükellefi üzerinde veya vergi mükellefi yurt dışındaki kurum üzerinde doğrudan veya dolaylı olarak yönetsel veya işlemsel ilişkiler açısından hâkimse bu kuruluşlar ilişkili şirket olarak kabul edilecektir.

\section{Emsal Fiyatın Tespitinde Kullanılan Yöntemler ve Belgelendirme}

Emsal fiyatın tespitinde kullanılan yöntemler öncelikli olarak Karşılaş̧ırılabilir Fiyat Yöntemi, Yeniden Satış Fiyatı Yöntemi ve Maliyet Artı Yöntemidir. 2011 yılında ise daha önce direktifler kapsamında kabul edilmiş olan Kar Bölüşüm Yöntemi, Bakiye Kazanç Analizi emsal fiyatın tespitinde kullanılmaya başlanmıştır. Ayrıca 2011 yılından itibaren mükellefler, somut olayın niteliğine uygun olarak en uygun yöntemi seçme konusunda serbestliğe kavuşmuşlardır (Yoshımura, 2013:45-46).

2010 yılında yapılan düzenlemeler ile mükelleflerin uymak zorunda oldukları belgelendirme yükümlülüğü ağırlaştırılmıştır. Mükellefler ilişkili şirketlerle yapmış oldukları tüm işlemlerin listesini ve emsal fiyata ulaşmak için 
kullandıkları yönteme ilişkin bilgilerin yer aldıkları belgeleri düzenlemek zorundadırlar (BDO,2011).

Japonya'da transfer fiyatlandırması işlemlerine yönelik özel bir cezai hüküm bulunmamaktadır. Mükellefler belgelendirme yükümlülügüne uymamaları veya ibraz yükümlülüklerini yerine getirmedikleri takdirde cezaya maruz kalmaktadırlar. Bu durumda \%10-\%15 arasında değişen cezai yaptırımlar söz konusu olacaktır. Mükellefin vergi kaçırdığında dair kanaatin oluşması durumunda söz konusu ceza \%35 oranına kadar yükselmektedir (TPA, 2015:2).

\section{Denetim Süreci}

Japonya'da büyük işletmelerin denetlenme riski yüksektir. Özellikle Ulusal Vergi İdaresi (National Tax Agency-NTA) tarafindan belirlenen sektörlerde faaliyet gösteren şirketler ile düşük kâr beyanında bulunan ya da vergi cennetlerinde yer alan şirketlerle mal ve hizmet alım satımında bulunan şirketler daha fazla denetime tabi tutulmaktadır. Ayrıca gayrimaddi varlıkların alım-satım işlemleri de transfer fiyatlandırması denetimlerinin odak noktasını oluşturmaktadır (TPA,2015:3).

Denetim süreci Ulusal Vergi İdaresi tarafindan istenilen belgelerin mükellef tarafindan otuz gün içerisinde ibraz edilmesiyle başlamakta ve ilk inceleme belgeler üzerinden yapılmaktadır. Eğer mükellef usulüne göre belgeleri tutmuş ise herhangi bir cezai yaptırım söz konusu olmamaktadır. Aksi durumda incelemeler derinleşmekte ve mükellefler ek matrah takdiri ile karşı karşıya kalmaktadırlar. Mükellef yasal süre içerişinde gerekli belgeleri ibraz etmezse bu durumda yetkililer aynı sektörde faaliyet gösteren diğer şirketin verilerinden hareketle oluşturdukları gizli emsal değerler üzerinden denetimlerini yapıp ek matrah takdirine gitmektedirler. Gizli emsal kullanımı dışında Japonya, Amerika Birleşik Devletleri ile FATCA anlaşması çerçevesinde bilgi alışverişinde bulunarak çok uluslu şirketlerin faaliyetleri hakkında bilgi edinebilmekte ve elde ettiği bilgileri transfer fiyatlandırması denetimlerinde kullanmaktadır (Yoshimura, 2013:42).

Tablo 1: Japonya'da Transfer Fiyatlandırması Kurallarına Aykırılık Nedeniyle Yapılan Ek Tarhiyatlar ve Matrah Tutarları

\begin{tabular}{|l|c|c|c|c|c|c|c|c|c|c|}
\hline & $\mathbf{2 0 0 3}$ & $\mathbf{2 0 0 4}$ & $\mathbf{2 0 0 5}$ & $\mathbf{2 0 0 6}$ & $\mathbf{2 0 0 7}$ & $\mathbf{2 0 0 8}$ & $\mathbf{2 0 0 9}$ & $\mathbf{2 0 1 0}$ & $\mathbf{2 0 1 1}$ & $\mathbf{2 0 1 2}$ \\
\hline $\begin{array}{l}\text { Yapılan } \\
\text { Tarhiyat } \\
\text { Sayıs }\end{array}$ & 62 & 82 & 119 & 101 & 133 & 111 & 100 & 146 & 182 & 222 \\
\hline $\begin{array}{l}\text { Eksik } \\
\text { Matrah } \\
\text { Miktarı( } \\
\begin{array}{l}\text { Milyar } \\
\text { Yen) }\end{array}\end{array}$ & 75,8 & 216,8 & 283,6 & 105,1 & 169,6 & 27 & 68,7 & 69,8 & 83,7 & 97,4 \\
\hline
\end{tabular}

Kaynak: (Yoshimura, 2013:43) 
Tablo 1 verileri değerlendirildiğinde, Japonya' da eksik matrah miktarında zirve değerine ulaşıldığı 2005 yılı değerlendirme dışı bırakıldığında incelenen dosya sayısında artış olmasına rağmen beyan dışı kalan matrah miktarı genellikle aynı seviyede seyretmektedir. Bunun nedeni ise son dönemde büyük inceleme dosyalarının olmaması ve/veya şirketlerin üzerlerindeki denetim riskini azaltmak için peşin fiyatlandırma anlaşmalarından yararlanmalarıdır. 2005 yılında tespit edilen eksik matrah miktarının diğer yıllara nazaran daha fazla olmasının nedeni ise bu yılda Japon Vergi İdaresi'nin büyük çok uluslu şirketlere agresif vergi tarhı yapmasıdır. Bu kapsamda Kyocera, Sony, Mazda Motor ve Takeda, Pharmaceutical Company gibi büyük şirketler sıkı bir şekilde denetlenmiş ve ek tarhiyat yapılmıştır (Yoshımura,2013:43).

\section{B.Hindistan}

Hindistan'da transfer fiyatlandırmasına ilişkin ilk düzenleme 1961 yılında Hindistan Gelir Vergisi Kanunu'nun 92. maddesi ile yapılmıştır. Söz konusu maddeye göre uluslararası işlemlerde ve yurt içinde yer alan ilişkili kişilerle yapılan işlemlerde emsallere uygunluk ilkesi esas alınmalıdır. Maddenin b fikrasında uluslararası işlemin tanımı yapılmıştır. Bu tanım uyarınca uluslararası işlem iki ya da daha fazla ilişkili şirket arasında gerçekleşen alım-satım, kiralama, maddi-gayri maddi varlık transferi, borçlanma, maliyet paylaşımı gibi işlemleri kapsamaktadir (PWC, 2015:476).

2001 yılında yapılan düzenleme ile ilişkili kişiler arasında gerçekleşen işlemlerde emsallere uygunluk ilkesine aykırı bir şekilde fiyat tespitinin yapılamayacağı tekrar vurgulanmış ve ilişkili şirket tanımı daha ayrıntılı bir şekilde ele alınmıştır (UN,2015:1). Buna göre; iki şirketin ilişkili şirket olarak kabul edilebilmesi için taşıması gereken şartlar (PWC, 2015:476):

- Oy hakkının doğrudan veya dolaylı olarak \%26'sı ve daha fazlasının belirli bir şirkette olmas1;

- Şirketler ürettikleri veya satın aldıkları nihai ürün veya hammaddelerin \%90'nı veya daha fazlasının fiyatını veya satış koşullarını karşı1lıklı olarak belirleyebilmesi,

- Şirketin toplam kredi hacminin \%10'na belirli bir şirketin garanti vermesi

- Yönetim kurulunun en az \%50'sinin belirli bir şirket tarafından atanmas1

- Her iki tarafin sahip olduğu fikri mülkiyet hakları (know-how, telif hakk1, patent, marka, lisans vb.) arasında bağımlılık bulunması gerekmektedir.

2012 y1lında yürürlüğe giren Mali Yasa (Finance Act) ile ertelenmiş ödemeler, leasing işlemleri, işletme yeniden yapılandırmaları da uluslararası işlemler kapsamında değerlendirilmeye başlanmıştır. Ayrıca bu yasa ile ulusal transfer fiyatlandırmasına ilişkin düzenlemeler de yapılmıştır (PWC, 2015:477). 


\section{Emsal Fiyatın Tespitinde Kullanılan Yöntemler ve Belgelendirme}

Hindistan; OECD üyesi olmamakla birlikte emsal fiyatın tespitinde OECD düzenlemelerinde yer alan bütün yöntemleri (Karşılaştırılabilir Fiyat Yöntemi, Maliyet Artı Yöntemi, Kar Bölüşüm Yöntemleri) kullanmaktadır. Yöntemlerin seçiminde herhangi bir öncelik sıralaması bulunmamaktadır. Mükellef durumuna en uygun yöntemi seçmekte serbesttir. Kendisinden bu konuda istenen tek şey yöntemi hangi gerekçelerle tespit ettiğini açıklamasıdır. 2015 yılı itibariyle Hindistan emsallere uygun fiyat aralığının tespiti ve çoklu yıl verilerinin kullanımı için yeni kurallar yürürlüğe koymuştur. Bu kurallara göre (Demirci, 2015:244);

- En az altı emsal şirket verisinin seçilmesi zorunludur.

- Veri setinin oluşturulmasında seçilen altı şirketin en az üç yıllık bilgilerinin dikkate alınması gerekmektedir.

- Her bir emsal için bulunan verilerin ağırlıklı ortalaması hesaplanmalidir.

- Emsal fiyat aralığını, veri setinin otuz beşinci ve altmış beşinci yüzdelik dilimi arasında kalan kısmı oluşturacaktır. Başka bir ifade ile belirtilen yüzdelik dilim aralığının dışında kalan veri setinin medyan değeri düzeltme işlemlerinde emsallere uygun fiyat olacaktır.

Hindistan'da transfer fiyatlandırması kapsamında ilişkili kişilerle gerçekleştirilen işlemlerin emsallere uygun bir şekilde gerçekleştiğini ispatlama önceliği mükellefe aittir. Belgelendirme yükümlülüğü kapsamında; ilk olarak mükellefin bilgilerinin yer aldığ 1 belgelerin tutulması zorunludur. Söz konusu belgelerde şirket profiline ilişkin bilgiler, faaliyette bulunan sektöre ilişkin bilgiler, yapılan uluslararası ve ulusal işlemlerin niteliği ve miktarı hakkında bilgilerin yer alması zorunludur. Bu kapsamda mükellef; sektör analizleri, ekonomik ve finansal analizleri ve işletmenin mali bilgilerini içeren diğer belgeleri yıllık olarak tutmalıdır. Bununla birlikte transfer fiyatlandırmasına ilişkin tutulması gereken en önemli belge Muhasebeci Raporu olarak da isimlendirilen "3 ECB" formudur. Söz konusu form, yeminli mali müşavirler tarafından işlemlerin gerçekleştiği dönemi takip eden Kasım ayının 30'na kadar yetkililere sunulmak üzere hazırlanmalıdır. Bu raporda şirket bilgileri, ilişki şirketlerle gerçekleştirilen işlemler, emsal fiyat tespitinde kullanılan yöntemler ve bu yöntemin neden seçildiğine dair analizlerin yer alması gerekmektedir (India Central Board of Direct Taxes,2015).

Hint transfer fiyatlandırması sisteminde mükellefin cezai yaptırımlardan kurtulması için belgelendirme yükümlülüğüne sıkı sıkıya uyması gerekmektedir. $\mathrm{Bu}$ kapsamda belirlenen cezai yaptırımları aşağıdaki şekilde özetlememiz mümkündür (KPMG,2015:3):

- Kanunlarda belirtilen belgelerde eksik ya da yanıltıcı bilgi verilmesi durumunda; gerçekleştirilen uluslararası işlem tutarının \%2'si,

- Muhasebeci Raporu'nun verilmemesi durumunda ise 100.000 Hint Rupisi (yaklaşık 2.000 \$) tutarında ödeme yapılması gerekmektedir. 


\section{Denetim Süreci}

2001 y1lında revize edilen transfer fiyatlandırması kuralları ile birlikte ülkede denetim sürecini daha etkin hale getirebilmek için 2003 yılında ayrı bir transfer fiyatlandırması denetim birimi oluşturulmuştur. Transfer fiyatlandırmas denetim birimi, incelenecek mükellefin seçiminde risk göstergelerinden yararlanmaktadır. Buna göre (TP Week, 2015:1);

- İlişkili şirketlerle gerçekleştiren mal ve hizmet transferlerinde kârlılık düzenli bir şekilde düşüş gösteriyorsa,

- Yönetici ücretleri emsallere aykırılık gösterecek kadar yüksek tespit edilmişse,

- Şirketlerin rutin tedarikçileri zarar beyanında bulunuyorsa ve sunulan hizmetler için düşük fiyatlandırma yapılmışsa denetim sürecinin başlatılması gerekmektedir.

Yukarıda bahsedilen risk göstergelerinin yanı sıra ülkede belli başlı sektörlerde transfer fiyatlandırması denetimleri yoğun ve sürekli olarak sürdürülmektedir. $\mathrm{Bu}$ sektörler; bilişim teknolojileri, otomobil sanayi, kimya sanayisi, ilaç sanayi ve finansal hizmetlerdir (KPMG, 2015:5).

Hindistan'da transfer fiyatlandırmas1 denetimlerinin odak noktasını mükelleflerin belgelendirme yükümlülükleri oluşturmaktadır. Dolayısıyla denetim sürecinin başlangıcını mükellefin kurumlar vergisi beyannamesini doldurması ve Muhasebeci Raporunu teslim etmesi oluşturmaktadır. Eğer söz konusu belgelerde yukarıda belirtilen risk göstergeleri de esas alınarak bir matrah farkı tespit edilirse denetim süreci başlamaktadır. Transfer denetimlerinde genel kural mali yılın bitmesini takip eden 33 ay içinde denetimin tamamlanması yönündedir. $\mathrm{Bu}$ süre en fazla 46 aya kadar uzayabilmektedir. Denetim sürecinde Hindistan'1n diğer ülkelerden farkı, mükellefin vergi denetim elemanının takdir ettiği matrah farkına itiraz hakkının olmasıdır. Buna göre mükellef öncelikle temyiz komisyonuna başvurur. Buradan cevap alamaması durumunda ise sirasiyla temyiz mahkemesi, yüksek mahkeme ve en son olarak da anayasa mahkemesine başvurmaktadır. $\mathrm{Bu}$ uygulama hem vergileme hatalarını azaltmakta hem de mükellef hakları korumaktadır (KPMG;2015:4).

Hindistan'da transfer fiyatlandırması denetimlerini daha etkin hale getirebilmek için çeşitli düzenlemeler yapılmaktadır. Bunlardan ilki; 2014 yılında ABD ile FATCA kapsamında çok uluslu şirketleri daha etkin vergilendirmek için bilgi değiş̧imi anlaşması imzalanmasıdır (Sharma,2014:2). Bir diğer gelişme ise Güvenli Liman uygulamasıdır. Hindistan vergi otoritesi, bu uygulama ile transfer fiyatlandırmasından kaynaklanan uyuşmazlıkları azaltmayı hedeflemektedir. $\mathrm{Bu}$ kapsamda Avustralya, Yeni Zelanda, Singapur ve ABD gibi ülkelerde uygulanan Güvenli Liman Kuralları 2013-2014 mali yılını takip eden beş yıl süreyle uygulanmak üzere 18 Eylül 2013 tarihinde kabul edilmiştir. Bu kurallar sayesinde transfer fiyatlandırmas1 denetimlerinden kaynaklanan maliyetlerin ve belirsizliklerin azaltılması hedeflenmektedir (TPA,2015). 


\section{C. Çin Halk Cumhuriyeti}

Çin'de transfer fiyatlandırması kurallarının oluşumu pilot programlar ile 1980'li yıllarda başlamıştır. Transfer fiyatlandırması kurallarının gelişimi incelendiğinde başlangıçta şirket kazançlarının vergilendirilmesinde yerel şirketler ile yabancı şirketler (Foreign-1nvested enterprises- FIEs) ayrımına dayanan ikili bir yapı söz konusudur. Bu yapıda yabancı şirketler çok sayıda teşvik hükmünden yararlanmaktadır. $\mathrm{Bu}$ dönemde birçok FIEs transfer fiyatlandırmasını, ilişkili şirketlerle gerçekleştirmiş oldukları işlemler dolayısıyla elde ettikleri kârlarını transfer ederek Çin'deki vergi yükümlülüklerini azaltmaya yarayan bir yöntem olarak görmüşlerdir. Bu kapsamda FIEs'lerin neden oldukları matrah kaybını önlemek için 1988 yılında ilk pilot çalışma Shenzhen Şehri Halk Hükümeti tarafından yapılmıştır (Markham ve Liao,2014:716-717).

$\mathrm{Bu}$ pilot düzenleme arkasindan Ulusal Halk Kongresi (National People's Congress-NPC) tarafindan 1991 yılında Gelir Vergisi Kanunu'nda yapılan düzenlemeler ile transfer fiyatlamasi konusunda ulusal düzenlemeler oluşturulmuştur (Chan ve Chow,1997:87). Gelir Vergisi Kanunu' nun 13. maddesi uyarınca ilişkili kişiler arasında emsallere aykırı olarak fiyat tespit edilerek vergi kaybına neden olunmuşsa vergi otoritesi düzeltme hakkına sahip olacaktır. Bu düzenlemeler sadece yabancı ilişkili kişiler arasında gerçekleştirilen işlemleri konu alıp yerel şirketlerle yapılan işlemleri düzenleme dışı bırakmaktadır. 1992 ve 1993 yılında yapılan düzenlemeler ile (Law of the People's Republic of China Concerning the Administration of Tax CollectionTCL ve Rules for the Implementation of the Law of the People's Republic on the Administration of Tax Collection-RITCL) transfer fiyatlandırması kuralları genişletilerek yerli ve yabancı tüm ilişkili şirketler arasında gerçekleşen işlemlerde transfer fiyatlandırması kurallarının uygulanacağı hüküm altına alınmıştır (Markham ve Liao,2014:718).

2007 y1lında hükümleri 1 Ocak 2008 tarihinden itibaren geçerli olacak Yeni Kurumlar Vergisi Kanunu (Enterprise Income Tax Law- EITLIR) yayımlanmıştır. Söz konusu kanun ile öncelikli olarak yerel şirketler ile yabancı şirketlere uygulanan hükümler birleştirilmiş, uygulamada bütünlük sağlanmıştır. Ayrıca yabancı yatırımcılara yönelik teşvikler azaltılarak yabancı yatırımların maliyetleri yükseltilmiştir (Y.M. Ng, 2010:50). Transfer fiyatlandırması konusunda düzenlemeler Kanunun 6. bölümünde yer almaktadır. Bu bölümde de öncelikle 1991 yılında yayımlanan Gelir Vergisi Kanunu madde 13'e atıf yapılarak emsallere uygunluk ilkesine vurgu yapılmış ve bu ilkeye aykırı uygulamalarda idarenin düzenleme hakkına sahip olduğu tekrar vurgulanmıştır (Ying, 2015:3-8). Emsallere uygunluk ilkesi vurgulandıktan sonra ilişkili kişi tanımı yapılmıştır. Buna göre; şirketler finansman, alım, satım gibi konularda doğrudan ya da dolaylı olarak kontrol yetkisine ve bunların dışında bir ortaklık ilişkisine sahipseler ilişkili kişi olarak kabul edileceklerdir. Ayrıca kanunda örtülü sermaye, peşin fiyatlandırma anlaşmaları ile maliyet paylaşım anlaşmalarına ilişkin hükümler de yer almaktadır. 2008 yılında yapılan bu reformun en önemli sonuçlarından biri de 
belgelendirme yükümlülügünü ağırlaştırması ve sistemi bu yükümlülüğün etrafında şekillendirmesidir. Belgelendirme yükümlülügü̈n ağırlaştırılması ve idare tarafından istenen bilgilere yer verilmesi şirketlerin raporlama sistemleri arasındaki farklılıkları ortadan kaldırarak denetçilerin daha kolay ve doğru bir şekilde şirketlerin mali bilgilerine ulaşmalarını sağlamıştır. Bu sayede transfer fiyatlandırması manipülasyonunun önlenmesi konusunda en sik1 uygulamalara sahip ülkelerden biri haline gelmiştir (L.Ho,2014:447). Ayrıca söz konusu kanun ile ilişkili kişiler arasında gerçekleşen işlemler; maddi varlıkların alım-satımı, gayri maddi varlıkların transferi, finansman ve hizmet sunumu olmak üzere dört gruba ayrılmıştır (Markham ve Liao,2014:726).

\section{Emsal Fiyatın Tespitinde Kullanılan Yöntemler ve Belgelendirme}

01.01.2008 tarihinden itibaren yürüklükte olan Yeni Kurumlar Vergisi Kanunu'nun 111. maddesi uyarınca; emsal fiyatın tespit edilmesinde öncelikli olarak kullanılması gereken yöntemler; Karşılaştırılabilir Fiyat Yöntemi, Yeniden Satış Fiyat Yöntemi ve son olarak da Maliyet Artı Yöntemi'dir. Bu üç yöntem ile emsal fiyat tespit edilemezse diğer yöntemlere başvurulmaktadır Uygulanabilecek diğer yöntemler ise; Karşılaştırılabilir Kar Yöntemi, Kar Bölüşüm Yöntemi ve emsallere uygunluk ilkesine uygun diğer yöntemlerdir.

2012 yılında yapılan düzenlemeler (The Internal Working Regulations for Special Tax Adjustment (Trial Version ve Regulations on the Joint Hearing of Major Special Tax Adjustment Cases) ile birlikte yerel idarelerin özellikle transfer fiyatlandırması denetiminde uyacakları kurallar tesis edilmiştir. Ayrıca bu düzenleme ile çok uluslu şirketler için "kendi kendini değerleme" uygulamasına geçilmiş ve özellikle yıllık cirosu 1 milyar RMB'yi aşan şirketler için özel bir değerleme mekanizması oluşturulmuştur. Yürürlüğe giren istatistik gösterge sistemi ile çok uluslu şirketlerin karlılıkları coğrafik yapı ve faaliyette bulunulan sektöre göre değerlendirilmektedir (Markham ve Liao,2014:720).

Çin'de transfer fiyatlandırması sistemi üçlü bir yap1 üzerinde ilerlemektedir. Mükellefin gönüllü uyumun ön planda olduğu bu sistemde yönetim, hizmet ve denetim aşamalarından oluşan bir yap1 söz konusudur. $\mathrm{Bu}$ yapı içerisinde APA anlaşmaları önemli bir yerdedir. APA anlaşmaları mükellef ile idare arasındaki ihtilafları azaltmak açısından da önemli bir yere sahiptir. Bir APA anlaşması şirketin başvurundan itibaren üç ila beş yıl arasında gerçekleşen tüm işlemler için geçerli hükümler içermektedir. 1998 yılında başlayan APA anlaşmaları 2002 yılından sonra yaygınlık kazanmıştır (SAT,2012:34).

İlişkili kişilerle gerçekleştirilen işlemler genellikle karmaşı ve idare ile mükellef arasında bilgi asimetrisiyle sonuçlanan işlemler olduğundan belgelendirme yükümlülüğüne uyulması sistemin işleyebilmesi için en önemli konuların başında gelmektedir. Çin'de şirketler yıllık beyannamelerini düzenlerken ilişkili şirketlerle gerçekleştirdikleri işlemlere ilişkin raporu beyannamelerine eklemekle yükümlüdürler. Söz konusu belgelerde aşağıda belirtilen bilgiler kendi içinde tutarlılık göstermelidir. Aksi takdirde mükellef yanlış ve eksik beyanda bulunmuş kabul edilecektir. Raporda; şirketin 
organizasyon yapısı, ilişkili kişilerle gerçekleştirilen işlemler ve seçilen transfer fiyatlandırması yöntemine ilişkin bilgilerin yer alması gerekmektedir (Markham ve Liao,2014:733).

Transfer fiyatlandırması belgelerinin idarenin talebi halinde yirmi gün içerisinde temin edilmesi gerekmektedir. Transfer fiyatlandırması manipülasyonu için sistemde özel bir ceza öngörülmemiştir. Bununla beraber transfer fiyatlandırması belgelerinin eksikliği durumunda cezai yaptırım olarak faiz işletilmesi söz konusudur. Söz konusu faiz oranı People's Bank tarafından uygulanan kredi faiz oranının maximum beş puan üzerinde olabilir. $\mathrm{Bu}$ faiz kurumlar vergisi matrahından düşülemez (KPGM, 2013:4).

\section{Denetim Süreci}

Dışa açılma sürecine bağlı olarak Çin'de çok uluslu şirketlerin sayısında artış olmasına karşlık bu şirketler kar beyanından daha çok transfer fiyatlandırması manipülasyonlarına başvurarak zarar beyanında bulunmuşlardır. Dolaysıyla transfer fiyatlandırması denetimi bu ülkede sıkı bir şekilde ele alınmıştır. Öncelikle maddi duran varlıkların denetimi üzerinde odaklanılmasına rağmen son yıllarda gayri maddi varlıklarda emsal fiyatın doğru bir şekilde tespit edilmesi önem kazanmıştır (Y.M. Ng, 2010:50).

Denetim sürecinde Çin Vergi İdaresi (China's State Administration of Taxation, SAT) sadece mükelleften elde ettiği bilgilerle yetinmemektedir. Bu bilgilerin yanı sıra yerel işletme bürolarından, bankalardan da bilgi toplamaktadır. Bunun yanı sıra uluslararası işbirliği kapsamında bilgi değişim anlaşmaları yoluyla da bilgi edinmektedir. Çin Vergi İdaresi tarafından yayımlanan sirküler uyarınca (Markham ve Liao,2014:734);

- İlişkili şirketlerle yüksek meblağlarda işlem gerçekleştiren mükellefler,

- Uzun süre zarar beyan eden veya düşük karla çalışan mükellefler,

- Vergi cennetlerinde mukim ilişkili şirketler ile ticari faaliyetleri olan şirketler,

- Transfer fiyatlandırması raporlarını eksik yerine getiren mükellefler, riskli mükellef olarak kabul edilecek ve denetime tabi tutulacaktır.

Çin' de denetim sürecinin başlangıç aşamasını ön inceleme aşaması oluşturmaktadır. $\mathrm{Bu}$ aşamada transfer fiyatlandırması dosyası yukarıda belirtilen riskli mükellef gruplarına ilişkin göstergeler de dikkate alınarak yerel düzeyde bir ön incelemeye tabi tutulur. Bu aşamadan sonra SAT tarafindan değerlendirilen dosya ya reddedilir ya da değerlendirilmek üzere yerel vergi birimine gönderilir. Yapılan değerlendirmeler sonucunda hazırlanan dosyanın sonuç raporu SAT'a tekrar gönderilir. İncelemeleri sonucunda SAT dosyayı sonuçlandırır. 
Tablo 2: Çin’de Geçmiş Yıllarda Sonuçlanan İnceleme Dosyaları ve Hasılat Tutarı

\begin{tabular}{|l|c|c|c|c|c|c|}
\hline & $\mathbf{2 0 0 6}$ & $\mathbf{2 0 0 7}$ & $\mathbf{2 0 0 8}$ & $\mathbf{2 0 0 9}$ & $\mathbf{2 0 1 0}$ & $\mathbf{2 0 1 1}$ \\
\hline İncelenen Dosya Sayısı & 177 & 174 & 152 & 167 & 178 & 207 \\
\hline $\begin{array}{l}\text { Yapplan Düzeltmelerin Yaklaşık } \\
\text { Tutarı (RMB Million) }\end{array}$ & 3,84 & 5,75 & 8,16 & 12,51 & 14,5 & 11,8 \\
\hline
\end{tabular}

Kaynak:(Ying,2015:3-8)

*RMB: Renminbi.Çin Halk Cumhuriyeti'nin resmi parasıdır, birimi Yuan'dır.

2008 yılından sonra arttırılan belgelendirme yükümlülüğ̈ ve neticesinde gerçekleştirilen denetim sonuçları Tablo 2'de gösterilmektedir. 2007 yılından itibaren Çin en s1k1 transfer denetimi uygulayan sayılı ülkelerden biri haline gelmiştir. 2012 yılı verileri değerlendirildiğinde yapılan denetimler sonucunda idare 26,2 milyar RMB tutarında matrah düzeltmesi yapmıştır.

\section{Kanada}

Kanada'da çok uluslu şirketlerin etkin bir şekilde vergilendirilmesi en önemli konuların başında gelmektedir. Ülkede şirketlerin farklı eyaletlerde yada ülkelerde elde edilen gelir konsolide edilmemektedir. $\mathrm{Bu}$ nedenle şirketler gelirlerini yüksek vergi oranı uygulayan eyaletlerden/ülkelerden düşük vergi oranı uygulayan eyaletlere/ülkelere kolaylıkla aktarabilmektedirler. Bu durumun ortaya çıkardığı matrah daralmalarından ötürü ülkede transfer fiyatlandırması konusu özel bir öneme sahiptir (Mintz ve Smart,2004:1156) .

Ülkede transfer fiyatlandırması mevzuatının temelini 1979 yılında Gelir Vergisi Kanunu'nun 69. bölümü oluşturmaktadır. Söz konusu kanunda en ciddi değişiklik ise 1998 yılında Gelir Vergisi Kanunu'nun 247. bölümü ile yapılmıştır (Pinto,2012:38).

\section{Emsal Fiyatın Tespitinde Kullanılan Yöntemler ve Belgelendirme}

Kanada'da transfer fiyatlandırmasi kurallarının temelini "emsallere uygunluk ilkesi" oluşturmaktadır. Emsal Bedelin tespitinde kullanılacak yöntemler ise IC87-2R kodlu sirküde düzenlenmiştir. Emsal bedel tespitinde OECD düzenlemelerine sadık kalınarak Karşılaştırılabilir Fiyat Yöntemi, Yeniden Satış Fiyatı Yöntemi ve Maliyet Artı Yöntemi ile Kar Bölüşüm Yönteminden yararlanılabilmektedir. Yöntemler arasında hiyerarşik bir öncelik olmamakla birlikte son dönemde kar bölüşüm yöntemlerinden yararlanılmaktadır (Borkowski,2010:37).

Transfer fiyatlandırmasında temel belge mükellefler tarafindan her y1l tutulmas1 zorunlu olan $\mathrm{T}-106$ kodlu belgedir. $\mathrm{Bu}$ belgede mukim olmayan kişilerle gerçekleştirilen alım-satım işlemlerinin tutarı, kredi miktarı, verilen avanslar, maddi/gayrimaddi hakların kira yâda satış bedelleri ve hizmet bedeli ödemelerine ilişkin bilgiler yer almaktadır. Ayrıca emsal bedelin tespitinde kullanılan yönteminde bu formda yer alması gerekmektedir. Bu belgede şirketin faaliyet alanı, organizasyon yapısı, ilişkili kişilerle gerçekleştirilen işlemlerin niteliği ve niceliğine ilişkin bilgiler, fonksiyonel ve ekonomik analizin yer alması 
gerekmektedir. T-106 kodlu belgenin geç verilmesi halinde günlük 25 Kanada Doları ceza kesilmektedir. Bu formun hiç verilmemesi halinde ise 12.000 Kanada Doları ceza kesilmektedir. Belgelendirme yükümlülüğüne uyulmamasından dolayı verilen cezanın yanısıra denetim sonrasında matrahta yapılan düzeltmenin \%10'nu oranında cezai yaptırım uygulanmaktadır (Canada Revenue Agency,2015).

\section{Denetim Süreci}

Son yıllarda kamu harcamalarının ve bütçe açıklarının artmasına bağlı olarak Kanada daha agresif vergi denetimleri yapmaya başlamıştır. Bu kapsamda mükelleflerin sınır ötesi yapmış oldukları işlemler de giderek önem kazanmıştır. Emsallere uygunluk ilkesine aykırı işlem gerçekleştiren her Kanada mükellefi denetime tabi olma riski taşımaktadır. Ülkede denetim alanında en önemli risk Amerika ve Kanada'nın emsal fiyat tespitinde farklı yaklaşımlar benimsemiş olmasıdır. İki ülke arasındaki işlem yoğunluğu düşünüldüğünde bu durumun varlığı çifte vergilendirme sorununu da beraberinde getirmektedir. Ülkede bazı durumların varlığ 1 halinde şirketlerin denetime tabi olma riski daha artmaktadır. Bu durumlar (Niradola vd., 2012:2):

- $\quad$ Şirketlerin birkaç dönemdir sürekli zarar beyanında bulunması,

- T-106 kodlu belgede yer alan bilgilerin eksik ya da hatalı olması,

- $\quad$ İşletme yeniden yapılandırmaları, gayrimaddi varlıkların transferi, şirketler

- Kullandıkları transfer fiyatlandırması yöntemini değiştiren

Kanada' da denetime başlanmadan önce Transfer Fiyatlandırması İnceleme Komitesi saha denetimlerini düzenlemek için bir ön inceleme yapmaktadır. Bu ön incelemede transfer fiyatlandırması denetimlerinin etkin bir şekilde yapılabilmesi uyulacak kurallar, uygulanacak cezalar hakkında değerlendirme yapılmaktadır. Ayrıca 5.000.000 \$ doları aşan incelemelerde mutlaka komite tüm denetim sürecini yönlendirmelidir. Denetim süreci CRA (Canada Revenue Agency)'nın mükellefe gönderdiği yazılı talebini içeren davet mektubu ile başlamaktadır. İspat yükümlülügü mükellefe ait olduğundan tutulması zorunlu belgelerde yer alan bilgilerin tam ve doğru olması mükellef lehine sonuç doğurmaktadır. CRA tarafindan talep edilen tüm belgelerin 3 ay içinde mükellef tarafından teslim edilmesi gerekmektedir. Denetim sürecinde sadece T-106 kodlu belgenin incelenmesi ile sınırlı kalınmamaktadır. Bunun dışında saha ziyareti, karşılıklı görüşme, iş akışlarının incelenmesi, diğer kurumsal defter ve kayıtların incelenmesi de söz konusudur. Bu kapsamda mükellefler; denetim sirasında yanlarında profesyonel danışman bulunabilme hakkına sahiptir. Ayrıca mükellef temyiz hakkına da sahiptir (Kroft, 2015:1-2).

\section{E. Amerika Birleşik Devletleri}

Faaliyet gösteren çok uluslu şirket sayısının fazlalığına bağlı olarak ABD'de transfer fiyatlandırması konusu üzerinde ciddiyetle durulmaktadır. Transfer fiyatlandırmasına yönelik temel düzenleme ABD Gelir Yasası (Internal Revenue Code, IRS)'nın 482. maddesinde yer almaktadır. Bu maddeye göre; 
"Aynı çıkar birliği tarafından doğrudan veya dolaylı olarak sahip olunan ya da kontrol edilen iki ya da daha fazla sayıdaki organizasyon, ticarethane için Bakanlık toplam geliri, gideri, kredileri bölüşürrebilir ya da tahsis edebilir. Bunun için söz konusu dağıtımın bölüşümün veya tahsisin vergiden kaçınmayı engellemesi ya da geliri açıkça yansıtması açısından gerekli görülmesi yeterlidir."

$\mathrm{Bu}$ düzenlemenin amacı; vergi mükelleflerinin ilişkili şirketler arasında gerçekleştirmiş oldukları işlemeleri kontrol altında tutarak bu işlemlerden doğan geliri kavramak ve vergi kaybını en aza indirmektir (Kapusuzoğlu, 2003:30). Söz konusu madde de şirketler arasındaki ilişkiyi ortak menfaat ilkesine dayandırarak düzeltme yetkisinin kullanımında idareye oldukça geniş yetki alanı tanımıştır ( Tokay Acar;2013: 135).

\section{Emsal Fiyatın Tespitinde Kullanılan Yöntemler ve Belgelendirme}

1962 yılına kadar yapılan yasal düzenlemelerde, ilişkili şirketler arasında yapılan dağıtımlarda özel bir yöntem öngörülmemiştir. 1962 yılında emsallere uygunluk ilkesinin kontrol edilemeyen işlemlerde uygulanacağ gündeme gelmiş olup 1968 y1lından itibaren transfer fiyatlandırmas1 uygulamalarında emsallere uygunluk ilkesi yasal bir nitelik kazanmıştır (Taşkın, 2012:141). ABD vergi sisteminde emsallere uygunluk ilkesi; serbest piyasa koşulları altında aralarında herhangi bir bağ bulunmayan tarafların gerçekleştirdikleri işlemlerde saptanan değer olarak tanımlanmıştır (Tokay Acar, 2013:136). 1968 yılında yapılan düzenleme ile emsal bedel tespiti için üç yöntem önerilmiştir. Bu yöntemler; Karşılaştııılabilir Kontrol Dışı Fiyat Yöntemi, Yeniden Satış Yöntemi ve Maliyet Art1 Yöntemidir (Biyan,2007:81).

1993 yılında yapılan düzenleme ile emsallere uygun fiyat ve bedele ulaşmak için "en iyi yöntem" kurallarının uygulanmasına izin verilmiştir. En iyi yöntem kuralına göre; mükellef elindeki verileri ve içinde bulunduğu şartları dikkate alarak gerçeğe en yakın bedeli tespit edebilmek için en uygun yöntemi tercih edecektir (Koyuncu,2005:395). Dolayisiyla bu ilkenin benimsenmesi ile birlikte yöntemler arasındaki hiyerarşiden vazgeçilmiştir. Bu yöntemin temel esasını; mükellefin bütün transfer fiyatlandırması yöntemlerini etkin bir şekilde değerlendirerek kendi durumuna ve şartına uygun ve güvenilir yöntemi seçmesi oluşturmaktadır (Saraç,2005: 92).

En iyi yöntem kuralının uygulanmasında; kontrol dışı işlemlerde karşılaştırma yapılamaması durumunda uygun istatistikî yöntemler kullanılarak bir fiyat aralığ1 veya kar marjı aralığ1 tespit edilecektir. Bu aralıkta yer alan seri dörde bölündükten sonra en düşük ve en yüksek \%25'lik dilim değerlendirme diş1 bırakılarak geri kalan kısım emsal bedel aralığı olarak dikkate alınacaktır. Yapılan incelemelerde tespit edilen değerin bu aralık içinde olması durumunda mükellefin beyanı esas alınacaktır. Aksi takdirde IRS tarafından düzeltme yapılacaktır (Iş1k,2005:102).

Mükellefler en iyi yöntem kuralına uygun olarak seçtiği yöntemin emsal bedele en uygun sonucu verdiğine dair belgeleri saklamak ve gerektiğinde ibraz 
etmek zorundadır. Bu belgeler aksi bir düzenleme bulunmadığı takdirde son vergilendirme döneminden itibaren üç yıl süre ile saklanmalıdır. Tutulması gereken belgeleri iki kategoride siniflandirmamız mümkündür(Koyuncu,2005:399):

- Temel Belgeler (Principal Documents): Temel belgeler mükellefe ilişkin genel bilgilerin yer aldığ 1 belgelerdir. $\mathrm{Bu}$ belgelerde mükellefin faaliyet konusu, organizasyon yapısı, emsal fiyatın tespiti için seçilen yöntem ve bu yöntemin neden seçildiğine ilişkin ekonomik analiz, yönteme esas oluşturan her türlü işletme içi veri yer almaktadır.

- Destekleyici Belgeler (Background Documents): Temel belgelerde yer alan varsayımları ve durumları açılayan belgelerdir.

ABD' de transfer fiyatlandırmasına yönelik cezaların OECD rehberinde yer alan kusurla orantılı olma, mevzuata uyum sağlamaya yönelik olma ve iyi niyetli mükellefin cezalandırılmaması ilkelerine uyum sağladığını söylememiz mümkündür. Transfer fiyatlandırmasına ilişkin cezalar beyannamelerin doğruluğuna ilişkin cezalardır. Bu cezalardan ilki emsal bedelin doğru bir şekilde tespit edilmemesi sonucunda uğranılan vergi kaybına ilişkin olarak hesaplanan "Işlemsel Cezalar (Transactional Penalty)" diğeri ise toplam vergi kaybı dikkate alınarak hesaplanan "Net Düzeltme Cezası" dır ( Kurdoğlu,2013:155).

- İşlemsel Cezalar (Transactionaly Penalty): Bu ceza; mükellefin satışa konu olan bir mal veya hizmet için belirlediği fiyat, ilgili kanunda belirlenen doğru fiyatın \%200 üzerinde veya \%50 altında ise uygulanır. Sebep olunan vergi kaybına ilaveten $\% 20$ oranında ceza uygulanır. Mükellefin uyguladığı fiyat; ilgili kanunda belirlenen doğru fiyatın $\% 400$ üzerinde veya $\% 25$ altında ise neden olunan vergi kaybına ilaveten $\% 40$ oranında ceza uygulanır (IRS, 2015:2)

- Net Düzeltme Cezası (Net Adjustment Penalty): Net düzeltme cezalarında ise çok uluslu şirketlerin farklı ülkelerde yer alan bağlı işletmeleri arasında gerçekleştirilen mal alımı ve hizmet ifaları sonucunda elde edilen brüt toplam gelir üzerindeki düzeltme 5 milyon Dolar'dan fazla ise eksik beyan edilen gelirin \%20'si oranında cezaya tabi tutulmaktadır.

\section{Denetim Süreci}

Transfer fiyatlandırmasının stratejik öneminin artmasına paralel olarak özellikle uluslararası büyük çaplı şirketlerin denetim süreçlerinin daha etkin işleyebilmesi için 2010 yılında transfer fiyatlandırması uzmanlarından oluşan bir birim kurmuştur (Transfer Pricing Operations, TPO). Söz konusu birim 14 Şubat 2014 tarihinde transfer fiyatlandırması denetimine ilişkin yol haritası yayımlanmıştır. Yayımlanan yol haritası ile yirmi dört aylık denetim sürecini planlama, yürütme ve çözüm aşaması olarak üç aşamaya ayrılmış ve her bir aşamada yapılacak faaliyetler belirtilmiş. $\mathrm{Bu}$ sayede uluslararası şirketlerin uyumlarının artması hedeflenmiştir. $\mathrm{Bu}$ üç aşama IRS tarafından uluslararası 
büyük işletmeler için yayımlanan denetim kalite standartlarına (The Quality Exemination Process - QEP) uygun olarak gerçekleşecektir. Ön denetim aşaması altı ay sürmekte olup bu aşamada şirketin transfer fiyatlandırmasına yönelik olarak tutmuş olduğu temel ve destekleyici belgeler (Form No:5471, 5472, 8833, $8858,8865)$ ile seçmiş olduğu transfer fiyatlandırmasına yönelik işlevsel analiz değerlendirilir. Sonrasında ise denetim sürecinin nasıl işleyeceğine dair şirket yöneticileri ile toplantı yapılmaktadır. Asıl denetimin gerçekleştiği ikinci aşama ise yaklaşık on dört ay sürmektedir. Bu aşamada IRS yetkilileri şirketin ilişkili şirketlerle gerçekleştirilen tüm faaliyetlere ilişkin bilgilerini emsalleri ile karşılaştırarak değerlendirmesi yapılır. Son aşama ise dört aylık bir süreci kapsamakta olup denetimin sonuçları şirket yöneticileri ile paylaşılır. Bu süreçte tespit edilen soruların nasıl çözüleceğine dair bilgi verilir. Mükellef otuz gün içerisinde kendisinden istenilen belgeleri IRS'ye teslim ederse herhangi bir cezai yaptırımla karşılaşmaz. Eğer belgeleri teslim etmezse denetim elemanları tarafından denetim raporu tamamlanır ve cezai hüküm kesinleşir (IRS,2015:2).

\section{SONUÇ}

Çağımızın en önemli ekonomik olgularından birisi sermayenin belirli şirketlerin elinde toplanması ve çok uluslu şirket olarak adlandırılan bu şirketlerin yatırım ve üretim faaliyetlerinin büyük değerlere ulaşmasıdır. Küresel ticaretin büyük bir kısmını ellerinde bulundurmaları ve ekonomik politikaları yönlendirme kapasiteleri nedeniyle çok uluslu şirketlerin ülke ekonomilerine olumlu ve olumsuz etkileri gerek akademik gerekse de politik tartışmaların temelini oluşturmaktadır.

Çok uluslu şirketler küreselleşmenin kendilerine sağladıkları imkânları etkin bir şekilde kullanmak suretiyle ülkelerin vergi gelirlerini erozyona uğratmakta buna karşın kârlarını maksimize etmeye çalışmaktadırlar. $\mathrm{Bu}$ kapsamda çok uluslu şirketler; örtülü sermaye, yeniden yapılandırma, anlaşma alışverişi, vergi cennetlerinde yatırım yapma veya kazancı vergi cennetlerine aktarma, transfer fiyatlandırması manipülasyonları gibi yöntemlerle agresif bir vergi planlaması yaparak vergi yüklerini minimum düzeyde tutmaya çalışmaktadırlar. Belirtilen diğer yöntemleri de kullanmalarına karşın transfer fiyatlandırması çok uluslu şirketlerin en çok başvurdukları yöntemlerden biridir. 2013 yılı itibariyle yetmiş yedi ülkenin ulusal mevzuatında ve BEPS'de yer alan eylem planlarında transfer fiyatlandırmasına yönelik düzenlemelere yer vermesi konunun önemini bir kez daha gözler önüne sermektedir.

Uluslararası vergi hukuku literatüründe transfer fiyatlandırmas1 düzenlemeleri önemli bir yeri işgal etmektedir. Uluslararası vergi hukukunda, transfer fiyatlandırması kar dağıtımı ve aktarımı boyutuyla ele alınmaktadır.

Çalışmada incelen diğer ülkelerde emsallere uygunluk ilkesi transfer fiyatlandırması işlemlerinin temelini oluşturmaktadır. Emsal bedelin tespitinde "emsallere uygunluk ilkesi” OECD düzenlemeleri temel alınarak açıklanmıştır. Geleneksel işlem yöntemleri tüm ülkelerin mevzuatında benimsenmiştir. Ancak işlemin niteliği gereği emsal bedelin tespit edilememesi durumunda diğer 
ülkelerden farklı olarak emsal bedel tespit edilebilmektedir. ABD seçilen ülkeler arasında mükellefe yöntem seçiminde en fazla serbestliği tanıyan ülkelerin başında gelmektedir. Ülkede benimsenen "En İyi Yöntem Kuralı" gereğince mükellefler işlemin niteliğine en uygun yöntemi seçmekte serbesttirler. Dolayısıyla yöntemler arasında herhangi bir hiyerarşi söz konusu değildir.

Tüm ülkelerde mükellefler ilişkili kişilerle gerçekleştirmiş oldukları işlemleri emsal fiyata uygun olarak gerçekleştirdiklerini ispat etmekle yükümlüdürler. Dolayısıyla incelenen tüm ülkelerde belgelendirme yükümlülüğünün ağırlaştırıldığı gözlemlenmektedir. Mükellefler beyanname verme yükümlülüklerinin yanı sıra her ülkenin ilgili vergi kanunlarında belirtilen bilgileri içeren belgeleri yıllık olarak düzenlemek ve bu belgeleri 3-5 yıl arasında değişen sürelerde saklamakla yükümlüdürler. Ülkeden ülkeye isimleri değişiklik gösterse de söz konusu belgelerde şirket bilgileri, ilişkili kişilerle gerçekleştirilen işlemlerin niteliği ve niceliği hakkında bilgiler ve kullanılan transfer fiyatlandırması yöntemine ilişkin bilgiler yer almaktadır. Vergi idarelerinin yürüttükleri denetimlerin başlangıç noktasını mükelleflerin belgelendirme yükümlülüğüne uyup uymadıkları oluşturmaktadır. Denetimler sonucunda kesilen cezalarda da incelen tüm ülkelerde belgelendirme yükümlülüğe uyulmaması durumunda para cezası uygulandığı ve son yıllarda bu cezaların daha da ağırlaştırıldı ğ 1 tespit edilmiştir.

Emsal bedelin tespitinde değerlendirilmesi gereken bir diğer konu da gizli emsal kullanımı gelmektedir. İdarenin kendi yetki ve imkânları ile tespit ettiği emsallere gizli emsal adı verilmektedir. OECD yapmış olduğu düzenlemelerde gizli emsal uygulamasının mükellefin savunma hakkını kısıtladığ 1 gerekçesiyle uygulanmaması gerektiği yönünde görüş bildirmiştir. İncelenen ülkelerin genel olarak OECD düzenlemelerine benzer şekilde gizli emsal kullanımına başvurmadıkları görülmektedir. Bu konuda süregelen tartışmalara rağmen Çin, Hindistan, Kanada kısmen gizli emsal kullanımına başvurmaktadır.

2008 krizi sonrasında ve çok uluslu şirketlerin vergi matrahlarını aşındırıcı faaliyetlerini artmasına bağlı olarak incelenen ülkelerin daha agresif vergi denetimleri yaptıklarını söylemek mümkündür. $\mathrm{Bu}$ kapsamda; Japonya, Hindistan, Çin, Kanada ve ABD transfer fiyatlandırması denetimlerinin en sert uygulandığı ilk beş ülkedir. Yapılan denetimler ve denetimler sonrasında yapılan cezalı tarhiyatlar değerlendirildiğinde matrah farkının \%10'nundan başlayıp \%70'ne kadar yükselmekte, vergi kaçakçılığına dair belirtiler olması durumunda cezalar ağırlaştırılmış şekliyle uygulanmaktadır. Ülkelerin cezalara ilişkin genel yaklaşımı değerlendirildiğinde belgelendirme yükümlülüğüne uyulmaması durumunda mükellefin karşılaşacağı para cezası yaptırımlarının giderek ağırlaştı̆̆ını söylemek mümkündür. 


\section{KAYNAKÇA}

Ateş, L. (2011). Transfer Fiyatlandırması ve Vergileme, Ankara: Turhan Kitapevi.

BDO. (2011). "The Recent Tax Reform in Japan", Transfer Pricing News, Say1:6, Mayss,2011,http://www.bdointernational.com/Publications/TaxPublications/Documents/T ransfer\%20Pricing\%20News_60511.pdf.

Biyan, Ö. (2007). Transfer Fiyatlandırması Yoluyla Örtülü Kazanç Dağıtımı. Mali Çözüm Dergisi,82,77-104.

Borkowsk1, S.C. (2010). Transfer Pricing Practices of Transnational Corporations in PATA Countries. Journal of International Accounting, Auditing and Taxation. 19,35-54.

Canada Revenue Agency, (2015). "Information Return of Non-Arm's Length Transactions with Non-Residents T-106 Summary Form". http://www.cra-arc.gc.ca/E/pbg/tf/t106/t10611e.pdf.

Chan, K.H. ve L. Chow, (1997). An Empirical Study of Tax Audits in China on International Transfer Pricing. Journal of Accounting and Economics, 23, 83-112.

Demirci, A. (2015). Uluslararası Vergi Dünyasından Haberler, Vergi Dünyast, 412, 244-252.

Fujimari, K., ve C. Okada, (2009). Chapter 16: Japan. Anuschka Bakker ve Belema Obuaforibo (Ed). Transfer Pricing and Customs Valuation: Two Worlds To Tax One, (s.441-460), Netherlands: IBFD.

India Central Board Of Direct Taxes, (2015). Transfer Pricing http://www.incometaxindia.gov.in/Pages/internationaltaxation/transferpricing.aspx.

IRS, (2015). The Section 6662(e) Substantial and Gross Valuation Misstatement Penalty ,http://www.irs.gov/pub/irs-apa/penalties6662_e.pdf>.

IRS, (2015). Quality Examination Process Reference Guide, http://www.irs.gov/pub/irsutl/qeprefguide10-01-10.pdf.

Işık, H. (2005). Çok Uluslu Şirketlerde Örtülü Kazanç ve Örtülü Sermaye, Ankara: T.C Maliye Bakanlığı Araştırma, Planlama ve Koordinasyon Kurulu Başkanlığı.

Kapusuzoğlu, T. (2003). Vergisel Yönden Transfer Fiyatlandırması. İstanbul: Oluş Yayıncılık, İstanbul.

Kara, M. C. ve E. Öz, (2016).Uluslararası Vergilemede Hibrit Uyumsuzlukları Etkisizleştirme Çabaları. Vergi Dünyası Dergisi, 416,232-238.

Koyuncu, M. (2005). Örtülü Sermaye, Örtülü Kazanç Dağıtımı ve Uluslararası Transfer Fiyatlandırması, İstanbul: Yıldız Yayım Reklam AŞ.

KPMG, (2015). $\quad$ India $\quad$ Transfer $\quad$ Pricing Review. https://home.kpmg.com/content/dam/kpmg/pdf/2015/10/tp-review-india-v3.pdf.

Kroft, Q. C. (2015). CRA Transfer Pricing Audit-Red Flags for Taxpayers http://mccarthy.ca/pubs/FEB2010_CRA_TransferPricing_Audits_Red_Flags_for_Taxpay ers.pdf.

Kurdoğlu, S. (2013) Transfer Fiyatlandırılmasında Yaptırımlar: Hafif mi Yoksa Ağır mı? (ABD Uygulamasının Türkiye İle Karşılaştırılması), Vergi Sorunları 295, 148-161.

L.Ho, J. (2014). How to Train a Toothless Dragon: Finding Room for Improvement in China's Transfer Pricing Regulations", Virginia Journal of International Law, 54,437-462.

Markham, M., and Y. Liao, (2014). The Development of Transfer Pricing in China", Australian Tax Forum, 29,715-744.

Mintz, J. and M. Smart, (2004). Income Shifting, Investment and Tax Competition: Theory and Evidence from Provincial Taxation in Canada. Journal of PublicEconomics, 88, 11491168.

Nirandola, S. ve P. Lindsay, ve S. Wong, (2012). Primer on Transfer Pricing Audit, Tax Law Bulletin, Mart,1-2.

Öcal, E. (2010). Transfer Fiyatlandırmasında "Fiyatlandırma"-1". Yaklaşım, 206, 38-40.

Pehlivan, O. (2006). Uluslararas1 Vergilendirme, Trabzon: Derya Kitapevi.

Pinto, O. M. (2012). A Comparison of Transfer Pricing Practices in Canada and China International Journal of Business and Social Science, 3/23,36-44. 
A. K. Çelebi \& P. Mastar Özcan / Transfer Fiyatlandırması Uygulamaları: Seçilmiş Ülkeler Açısından Bir Değerlendirme

PWC. (2015). Section 38.India, International Transfer Pricing 2013/14, http://www.pwc.com/gx/en/international-transfer-pricing/assets/india.pdf,

SAT. (2015). China Advance Pricing Arrangement Annual Report 2012, http://www.chinatax.gov.cn/n810219/n810724/c1108851/part/1108853.pdf,

Taşkın, Y. (2012). Transfer Fiyatlandırmasında Emsallere Uygunluk İlkesi. Ankara: Türkmen Kitapevi.

Tokay Acar, U. O. (2013). Transfer Fiyatlandırması, Ankara: Seçkin Yayıncılık.

TPA. (2015). Safe Harbour Rules in India, http://www.tpaglobal.com/files/StreamFile193079/download/131010_safe-harbour-rules-final.pdf.

TP WEEK. (2015). How to Survive a Transfer Pricing Audit in India http://www.tpweek.com/Article/1935635/How-to-survive-a-transfer-pricing-audit-inIndia-.html.

UN. (2015). Emerging Transfer Pricing Challenges in India. .http://www.un.org/esa/ffd/wpcontent/uploads/2014/09/8STM_Chap10_CPIndia_2012090 4_v3_HC-accp.pdf

Y.M.Ng, C. (2010). The New Transfer Pricing Rules and Regulations in China- Impact on Foreign Investors, International Tax Journal, March-April, 50,

Ying, Z. (2015). China's Transfer Pricing System, http://www.taxjustice.net/cms/upload/pdf/Zhang_Ying_1206_Helsinki_ppt.pdf.

Yoshımura, N. (2013). Japonya'da Transfer Fiyatlandırmalarına İlișkin Düzenlemeler ve Bunların Uygulanması, Funda Başaran Yavaşlar (Ed). Uluslararası Tartışma Ortamında Transfer Fiyatlandırması Sempozyumu Bildiri Kitabı (41-50). İstanbul: Marmara Üniversitesi Yayınevi.

\section{SUMMARY}

The manipulation of transfer prices by the multi-national companies that have become the determinative factor during the globalization process, in other words preferring the method of paying lower tax or no tax by assigning higher or lower prices than their precedents, cause the depreciation of countries' tax base. Within this context, the pricing of realized transactions between related parties is significant in terms of accurately determining taxable incomes.

When the negative effects of tax incomes are taken into account, the arrangements of transfer pricing rules do appear as a necessity. Within this scope, a legal infrastructure is created by the legislative arrangement of both multinational companies and countries. Although a legal infrastructure is created to prevent loss of tax base, states face tax losses in significant amounts caused by the lack of effective tax auditing and manipulations of transfer pricing.

The aim of this study is primarily to analyze the arrangements regarding taxation of multi-national companies and transfer pricing as well as considering the recent developments in the subject area; and then shed a light on similar and different aspects of tax auditing processes regarding the transfer pricing in Turkey and selected countries.

The differences between both their legislations and governing structures of the countries are introduced when their approaches towards the transfer pricing auditing process are defined. The most significant constraint herein is that results of the transfer pricing auditing are included within the tax auditing results and that the countries are reluctant to share data within the scope of taxpayer rights. 